\title{
Reserzch Article: Rainfall pattern of Chinnamanur block, Theni district, Tamil Nadu
}

\section{R. VINOTHKUMAR, P. MARIMUTHU AND P. PATCHAIMAL}

Article Chronicle: Received : 17.07.2017;

Accepted :

01.08 .2017

\section{KEY WoRDs:}

Rainfall pattern, Mann-Kendall test, Sen's slope estimator, Regression
SUMMARY : Identification of temporal variation of rainfall trends provides useful information for sustainable planning and management of water resources in dryland area particularly during flood and drought periods. The present study was conducted to determine trends in the annual and seasonal total rainfall over Theni district of Tamil Nadu using 36 years (1981-2016) monthly rainfall data at Chinnamanur rain-gauge station. The procedure is based on the nonparametric Mann-Kendall test for the trend and the nonparametric Sen's method for the magnitude of the trend. The results indicated significant positive trend were observed during Summerseason followed by North East monsoon rainfall series and significant negative trend has been noticed in the South West monsoon season. The maximum increase in rainfall was found an annual rainfall of $1.18 \mathrm{~mm} /$ year and the maximum reduction in rainfall of $-0.87 \mathrm{~mm} / \mathrm{year}$ was found during South West monsoon. The presence of trend in annual and seasonal rainfall series determined by Mann-Kendall Z statistics and Sen's Slope estimator reflected in the linear regression analysis.

How to cite this article : Vinothkumar, R., Marimuthu, P. and Patchaimal, P. (2017). Rainfall pattern of Chinnamanur block, Theni district, Tamil Nadu. Agric. Update, 12(TECHSEAR-6) : 1557-1562; DOI: 10.15740/ HAS/AU/12. TECHSEAR(6)2017/1557-1562.
Author for correspondence :

\section{R. VINOTHKUMAR} CENDECT, ICAR KVK, Kamatchipuram THENI (T.N.) INDIA Email: kumar.nanthu@ gmail.com 